\title{
Comparative Interpretation of Classical and Keynesian Fiscal Policies (Assumptions, Principles and Primary Opinions)
}

\section{Engin Öner}

Associate Professor, Department of Public Finance

Yuzuncu Yil University, Faculty of Economics and Administrative Sciences, Van, 65080, Turkey

\begin{abstract}
Adam Smith being its founder, in the Classical School, which gives prominence to supply and adopts an approach of unbiased finance, the economy is always in a state of full employment equilibrium. In this system of thought, the main philosophy of which is budget balance, that asserts that there is flexibility between prices and wages and regards public debt as an extraordinary instrument, the interference of the state with the economic and social life is frowned upon. In line with the views of the classical thought, the classical fiscal policy is based on three basic assumptions. These are the "Consumer State Assumption", the assumption accepting that "Public Expenditures are Always Ineffectual" and the assumption concerning the "Impartiality of the Taxes and Expenditure Policies Implemented by the State". On the other hand, the Keynesian School founded by John Maynard Keynes, gives prominence to demand, adopts the approach of functional finance, and asserts that cases of underemployment equilibrium and overemployment equilibrium exist in the economy as well as the full employment equilibrium, that problems cannot be solved through the invisible hand, that prices and wages are strict, the interference of the state is essential and at this point fiscal policies have to be utilized effectively.Keynesian fiscal policy depends on three primary assumptions. These are the assumption of "Filter State", the assumption that "public expenditures are sometimes effective and sometimes ineffective or neutral" and the assumption that "the tax, debt and expenditure policies of the state can never be impartial".
\end{abstract}

Key words: Classical Fiscal Policies; Keynesian Fiscal Policies; Primary Assumptions; the full employment equilibrium; underemployment equilibrium and over-employment equilibrium.

JEL Classification: H30; E6; E24.

\section{Introduction}

The founder of the classical economy is Adam Smith and the main economists of this school are David Ricardo, Jean Baptiste Say, Thomas Malthus and John Stuart Mill. The economy is always in full employment balance in this school adopting the neutral fiscal approach that takes the supply to the forefront. The conditions of perfect competition are of priority in the classical economy whose main philosophy is the balance of budget. The intervention of the state in the economic and social life is never desired in this thought system which argues that there is a flexibility in the prices and costs and which sees the public debt as an extraordinary tool.

The founder of Keynesian economy is John Maynard Keynes and other main economists are James Tobin, Lawrence Klein, Alvin Hansen and Paul Samuelson. The demand is in the forefront and the functional fiscal 
approach has been adopted. In this school in which the existence of the deficient and excessive employment balance situations in the economy as well as the full employment are indicated; it has been asserted that the prices and costs are strict, the problems could not be solved with an invisible hand and certainly the intervention of the state is compulsory; at this point, it is emphasized that the fiscal policy (the policies of tax, expense and budget together with the debt that is accepted as an ordinary type of income) be used effectively.

Within the direction of the views of the classical thinking, there are three main assumptions of the classical fiscal policy. These assumptions are "Consumer State Assumption", "The Assumption That the Public Expenditures are Always Ineffective" and "The Assumption That the Tax and Spending Policies Applied By the State Should be Impartial'.

The classical budget which has been developed as based on these assumptions has five main principles. These are; "The budget of the state should be equal", "The budget of state should be small", "The public expenditures should be financed from the indirect taxes", "Normal budget deficits should be compensated from the financial market, namely the short-term debts" and "Extraordinary budget deficits should be compensated from the capital market, namely the longterm debts".

Three main assumptions have been put forth in the Keynesian fiscal policy against the assumptions of the classical fiscal policy. These are "the assumption of filter state”, "The Assumption That Public Expenditures and Services are sometimes effective and sometimes ineffective or neutral" and "The assumption that the tax, debt and spending policies of the state could never be impartial". The examination of the mentioned assumptions and principles in more detail shall reveal the viewpoints of these thought systems to the fiscal policy;

\section{Basic Assumptions of the Classical Fiscal Policy}

The classicals have seen the state as consumer, asserted that its expenditure shall always be ineffective and desired the tax and expenditure policies of the state to be impartial (Kamalak, M. 1985: 43; Türk, İ. 1988: 6-7)

\section{A. Assumption of Consumer State}

According to this assumption, the Classicals see the state as a gendarme state. Namely, he state shall only present the services such as justice, diplomacy, public works, internal and external security; shall never intervene in the economical, social and cultural life and the market (Eker, A. \& others. 1994:22; Devrim, F. 1996:181; Savaş, V. F. 1997:293).

Because the state is clumsy, consumer and it wastes every work it intervenes. According to the classical economist David Ricardo, the state is an obligatory bad/compulsory evil (Ay, H. 2014: 44). Classical economists are insecure towards the state and have not tolerated its intervention to the economic life (Orhaner, O. 1992: 21). According to Adam Smith, "The individual is always in a struggle to be able to use its own capital in the most advantageous way. What is important for him/her is not the advantage of the society, but his/her own advantage. However, his/her effort in trying to provide his/her advantage naturally ensures him/her to prefer the most advantageous employment for the society and even it requires this. Firstly, each individual would like to use the capital in a place close to his/her surroundings and for this reason, $\mathrm{s} /$ he acts in the direction of supporting the domestic industry as much as possible (Smith, A. 2002: 40); secondly, each individuals using his/her capital in a way that does not support the internal industry directs this industry inevitably to attain the product at the highest value that is possible (Smith, A. 2002: 42).

According to Smith, "Each individual inevitably tries to increase the annual income of the society as much as possible. S/he actually neither tries to increase the public advantage, not $\mathrm{s} /$ he has any idea in the issue of how much $\mathrm{s} / \mathrm{he}$ increases this. S/he supports the state industry instead of the foreign industry and tries only to take himself/herself under more protection; and while this industry directs his/her product in a way that shall increase the value to the highest, s/he only focuses on his/her own advantage and as it is valid in many other situations, $\mathrm{s} /$ he shall have worked for the realization of a target $\mathrm{s} /$ he has never intended to by an invisible hand. Likewise, the fact that $\mathrm{s} /$ he does not have this intention does not pose any disadvantage for the society. By running after his/her own advantage, s/he increases the advantage of the society in most time more than the way $\mathrm{s} /$ he pays attention to the advantage of the society" (Smith, A. 2002: 42). This viewpoint expresses that the balance in the economy shall occur by itself and there is no need for any power such as state etc.

Adam Smith reveals that the individual shall act more rationally in the capital use with his statement "it is clear that an individual shall assess far better than any statesman or lawmaker all of the country industry s/he 
could operationalize with his/her capital and which product shall probably have the highest value".

B. The Assumption That the Public Expenditure is Always Inefficient: This is an assumption which has developed by considering the first assumption. All kinds of public services made by the state shall not be advantageous, but disadvantageous. Because the state is clumsy and waster, whatever it does, the services and expenditure shall always be ineffective.

C. The Assumption That The Tax and Expenditure Policies of the State Should Be Impartial: The taxation policy made by the state should not positively or negatively affect the society and people. Namely, it should stay impartial. The Classical economists have put forth that the tax should only be the "feeding source of the treasure" (Dikmen, O. 1995:26). According to the classical understanding, the state should collect the highest amount of tax with the least amount of cost in a way that it shall not hinder the running of the market mechanism and the full competition conditions according to the financial power of everybody for the purpose of meeting the public expenditure (Özkara, M. 2014).

\section{Basic Principles of the Classical Budget}

The basis of the classical budget view consists of the state not interrupting in the economy and keeping the public services too limited ( Akdoğan, A. \& others. 1986: 106). The basic principles of the classical budget (the principles of the classical fiscal policy) have been determined as based on the assumptions. These are (Kamalak, M. 1985: 43-46; Türk, İ. 1988: 2-4);

-The Budget of the State Should Be Equal (Fiscal Balance): In the classical finance, "The budget of the state should always be equal, it should be kept out of the economical and social life, it should not have any competitive qualification." This is the basic aim in the classicals. The balance of the budget is the numeral equality of the income and expense items in the budget. The budget deficit is inflationary and the budget excess is deflationary. Both of them are the states of instability. The classicals are afraid of this situation. If the budget is equal, then everything is fine. This aim is the basic philosophy in the classicals. Today, the equality is only a means. The budget deficit is existent in the developing countries generally. The equal budget is a policy used for the struggle with inflation with low ratio in the developed countries.

-The Budget of State Should be Small: If the income taxes of the state is little, in return for this, its expenses shall also be little. Therefore, the state that is clumsy itself and consumer shall not be able to unbalance the economy and shall not be able to waste the fertile resources to be used by the private economy. According to the classicals, the budget should be small and also equal in terms of volume (Orhan, O.Z. 1989:64; Bilici,N. \& A. Bilici, 2011: 216; Pehlivan, O. 2014: 70) The stinginess of the state is the basis of the classical finance (Edizdoğan, N. 2007: 43).

-The Public Expenditures Should be Financed with Indirect Taxes: The classicals are against the state to get tax from the income, fortune etc. on the direct income resources. They have asserted that all the services should be met by the indirect taxes. There are two aims here;

i. According to the classicals, making saving is a virtuous behavior. Therefore, they have desired to minimize the efficiency of the state (decrease to the minimum level) and decrease the indirect taxes taken on the consumption.

ii. In addition, it has been desired to stop the waste of these resources by the state by preventing the state to get tax from the direct income resources.

-Normal Market Deficits Should be Compensated From the Financial Market, Namely Short-Term Debts: The idea of annual balance has never been abandoned. Namely, there is balance at the beginning and end of the term. During the year, temporary deficits occur in some months depending on the seasonal movements and conjunctural movements or the period. In the period in which the income has been little and expenditures have been much, treasure and Central Bank resources are applied, short-term debts are taken and problems are tried to be solved.

-Extraordinary Budget Deficits Should be Compensated From the Capital Market, Namely Long-Term Debts: The fact that the state is incapable of doing something in compensating for the high costs occurring in the extraordinary situations such as great wars and great crises has directed the classicals objecting to the debt to this means. The solution of the problems have been desired by taking long term debts from the capital market that is a great market, but the application could not be successful.

\section{Assumptions of the Keynesian Fiscal Policies}

The Keynesian theory criticizing the assumptions of the classicals has put forth that the state plays the role of 
filter-redistribution, it has expenditures some of which are effective and some of which are not effective, tax and expenditure (and debt) policies cannot be impartial (Kamalak, M. 1985: 52-53; Türk, İ. 1988: 12-14);

A. Assumption of Filter State: In the work of J. M. Keynes called "General Theory of Employment, Interest and Money" in 1936, he objects to the understanding of impartial state and asserts that the state should have an active role especially with the public expenditures in the management of the national economy and solution of unemployment (Giray, F. 2010: 31), the authoritarian state order of today is in a situation which could solve the unemployment (Keynes, J. M. 1936: 240; Keynes, J. M. 2008: 322). Therefore, Keynesians have argued that the state should interrupt in the economy by undertaking new tasks in the realization of the macro aims such as ensuring the economical stability, provision of the economical development, efficient use of the resources, ensuring the fair distribution of income and fortune, incenting the investment and savings, decreasing the deficits of foreign trade, being able to prevent unemployment and incenting the production and consumption; namely by undertaking new tasks in the economical and social areas; and they have stated that it should undertake a regulating role with the expenditure and debt policies (Turhan, S. 1975:249; Aktan, C. C. 1992:39). Keynes have put forth that "because the saving of the people is dependent on the income expected to be attained in the future, it is also dependent on the fiscal policies of the state as well as the interest ratio of the mentioned saving and the incomes taxes and other taxes are efficient as much as the interest ratio (Keynes, J. M. 2008: 89) and he has revealed the importance of the fiscal policy from this perspective, too."

Keynes has shown the "market unsuccess" as the justification for the intervention of the state to the economy (Bilici,N. \& Adem Bilici, 2011: 217). Therefore, Keynes has seen the intervention of the state to some social facilities with some kinds of economical and financial precautions as obligatory. He has asserted the idea that the tools of the fiscal policy should be benefited with importance and priority (Nadaroğlu, $\mathrm{H}$. 1985: 99). According to the Keynesian theory, the state is active. It is the state of social wealth. It is obligatory for the state to intervene in the economical, social and cultural life to "terminate the injustice in the income and wealth distribution" (Aksoy, S. 1998: 174) and to be able to overcome the problems certainly. The role of the state is crucial at the point of collectivist services towards the social and communal benefit which is avoided by the private sector by not finding profitable. State realizes this in three ways;

i. By acting as the entrepreneur in the
private sector,
ii. $\quad$ By means of the real expenditure (humane
investment, training expenditures, etc.),
iii. By means of the transfer expenditures
(Türk, İ. 1988: 13).

B. The Assumption That the Public Expenditures and Services Are Sometimes Effective and Sometimes Ineffective, Namely Neutral: As the Classicals argue, it is wrong to say that all of them are ineffective. Some of the public expenditures are effective for the social and communal benefit. Some public expenditures are ineffective or neutral. In other words, "there also may be the public enterprises which are as effective as the private enterprise or even more effective than that" (Türk, İ. 1988:14).

C. The Assumption That the Tax, Debt and Expenditure Policies of the State Could Never Be Impartial: Keynesian has accepted that the economy private sector is unbalanced and puts forth that there is a need for the intervention of the state to the economy for the purpose of terminating this problem; it is stated that the tools of fiscal policy (expenditure and tax policy) shall affect the total demand (Güngör, K. 2014).

The applications to be implemented by the state shall certainly cause to some kinds of impacts. For example, while the state uses tax, debt and expenditure tools in the struggle with inflation, it may move against a part of the society. For example, in the struggle with inflation, using taxation at the point of decreasing the consumption in especially short term shall have a negative impact on those with low income. In long term, success with inflation shall also reflect positively on those with low income. Therefore, all the policies shall certainly affect the society and private sector negatively or positively; and impartialness shall not be existent because the tax, debt and expenditure policies shall be used for the economical, fiscal and social purposes.

\section{Comparative Basic Views}

A. The understanding of impartial finance is dominant in the classical theory (Bilici,N. \& Adem Bilici, 2011: 216). "What is called as the invisible hand is the price mechanism" (Bocutoğlu, E. 2009: 5; Pehlivan, O. 2013: 52). Classical Theory is based on the long term in the solution of the economic problems (Vitez, O. 2014). In Classical theory, the doctrine "laissez-faire" "let them do it" that foresees to minimize the intervention of the 
state to the economy in the issue of the public expenditures is adopted and according to this view, state is the greatest waster spender unit of the society (Giray, F. 2010: 30).

The Keynesian theory is based on the short term and it focuses on the factors determining the production and employment in short term (Bocutoğlu, E. 2009: 162).

Functional finance is existent that is used in the solution of the economical depressions by using the public finance as a tool against the impartial finance (Erginay, A. 1990: 241). Functional finance is a view that covers all of the voluntary fiscal policies and that gives an active role to the state in the economy (Aktan, C.. C. \& others. 2010: 4). Lerner expresses that "taking into consideration the fiscal policy tools such as the expenditure, tax, debt, debt re-payment, coining and withdrawals not according to the rules of the classical doctrine, but according to their impact in the economy is the essential idea ...;" and he calls the assessment of these fiscal tools according to their impacts on the economy or their style of working as the "functional finance" (Lerner, A.P. 1943: 39). Lerner has asserted that the state should use all of its power to "prevent the depression and protect the value of the money" (Lerner, A.P. 1947: 314; Forstater, M. 1999). In other words, the functional fiscal approach of Lerner emphasizes the efficiency of the money and fiscal policies in reaching the macro aims such as full employment, price stability, balanced economical growth etc. (Forstater, M. 2008: 531).

B. In the classical theory, the equity of saving investment is determined via the interest rate (Öztürk, N. 2012: 26); when the savings are more than the investments, the interest rate decreases, the demand of investment increases and the equity of saving investment is ensured; when the investments are more than the savings, the interest rate increases, the demand for investment decreases because the investment gets expensive and the equity of investment saving is ensured;

In the Keynesian theory, the interest rate determines the money supply and money demand (Türk, İ. 1988: 9). If the money supply is more than the money demand, the interest rate shall decrease, the demand for money shall increase and as a result, the money supply and demand shall be equal; if the money supply is less than the money demand, the interest rate shall increase, the demand for money shall decrease and the money supply and demand shall become balanced;

C. The Classical Theory is based on the total supply. Say's law is valid. Namely, "each supply creates its own demand" (Bocutoğlu, E. 2009: 6; Bilici,N. \& Adem Bilici, 2011: 216; Chan, F. 2014). Law of Markets that is formulated as "each supply creates its own demand" by Jean Baptist Say and which assumes that all the income that has been attained shall be completely spent is an expression of the philosophy and belief of the classical economy theory ( Nadaroğlu, H. 1985: 96). The most important factor determining the magnitude of the total demand is the total supply. If the total supply increases, the total demand shall increase; if the total supply decreases, the total demand shall decrease (Bocutoğlu, E. 2009: 163). "The fact that the crises shall not be connected to the economical structure of the capitalist system in any way and the fact that the liberal economical activities shall realize a perfect fit in the economical life were explained with the concept of "invisible hand" developed by Smith until his work "A Memoir on the Economy Politics" was published in 1803 by J. B. Say. Together with the publication of this work; the "invisible hand" left its place to the doctrine of "loi des débouchés" which is also known as the Mahreçler Kanunu in the Turkish literature and which has been translated to English as "law of markets" which shall also be called as Say's Law later on (Aydın, Y. 2013: 82).

Keynesians have asserted that the economy is not always in balance in the full employment, the volume of employment shall not always increase as a result of the decrease in the price level and each product supplied to the market shall not be able to create its own demand (Bilici,N. \& Adem Bilici, 2011: 216). In short term, the most important factor determining the magnitude of the total supply is the total demand. For example, if the total demand increases, the total supply shall increases and if the total demand decreases, the total supply shall decrease. In the Keynesian Theory, the principle "each demand creates its own supply" is valid (Bocutoğlu, E. 2009: 163). The essential message in the General Theory which has caused to various discussions as of the day it has been published is in the direction that "the crises shall exist and the main reason for them is the insufficiency of demand"; therefore, "Say's Law cannot be valid" (Aydın, Y. 2013: 82); "In an economical system in which the state is not included as an unstabilizer element, the expectation of the crises in the efficient scale shall be normal" (Bocutoğlu, E. \& A. Ekinci 2009: 80).

Keynesians believe that the total demand is affected by means of the monetary and fiscal policies (especially the tax and expenditure policies) by the public and private section decisions (Jahan S. \& others, 2014: 53; Blinder, A.S. 2014). Effective demand expresses the total of the 
consumption and investment expenditures in the model of Keynes (Nadaroğlu, H. 1985: 100). In other words, effective demand is equal to the total of the expenditures actually realized in a certain period (Edizdoğan, N. 2007: 44). According to Keynes, "the overlap of the effective demand with full employment is a special situation which shall occur in the event that only consumer tendency and stimulated investments are in a certain relation with each other" (Keynes, J. M. 2008: 35).

D. According to the Classical Theory, the individuals only demand money with the process (treatment) motive. In other words, "money is a tool of exchange that only facilitates the exchange" (Aktan, C.. C. \& others. 2010:2)

In return for this, according to the Keynesian Theory, the individuals demand money with the process motive, caution motive and speculation motive ( Bocutoğlu , E. 2009: 164).

E. According to the Classical Theory, economy is at the balance of full employment by itself and all the time (Chan, F. 2014). There is an employment in which everyone with the working desire and power could find job from the current price and all the resources are used with full capacity (Pettinger, T. 2008; Nash, J. 2014; Öztürk, N. 2012: 20; Pehlivan, O. 2014: 53).

In the Keynesian theory, the economy may not always be at the level of full employment, it may be in the one of the balance status of deficient, full or excessive employment (Türk, İ. 1988: 9; Nash, J. 2014 ).

F. According to the classical theory, while the balance of budget which means the equality of the public incomes and the public expense is important.

According to the compensating budget theory that is based on the economical ideas of Keynes, the balance in budget is not important, what is important is the general balance of the economy (economical balance) at full employment level (Öztürk, N. 2013: 236-237; Pehlivan, O. 2014: 73)

G. According to the Classical Theory, the full competition conditions are valid in the labor, goods and financial markets. While "let them do it, let them pass" idea which is applied to all of the institutions of the free competition is taken as the basis and there is a market in which there is no intervention of the state. According to the Keynesian Theory, the deficient competition conditions are valid in the labor, goods and financial markets (Bocutoğlu, E. 2009: 162).
H. According to the Classicals, interest is the result of decreasing the consumption. Because making saving is a "virtuous" (Türk, İ. 1988: 4) attitude, the cost of giving up consumption and therefore, making saving is called as the interest; according to the Keynesians, interest is the result of giving the money up (giving the liquidity up). As the interest rate increases, the liquidity option decreases and as the interest rate decreases, the liquidity option increases (Türk, İ. 1988: 9).

I. According to the Classicals, while debt is an extraordinary public income; according to Keynesians, it is an ordinary income type. The Classicals should avoid from the debt. A. Smith "has not leaned towards the state to go into debt. He has expressed that going into debt shall cause to higher amounts of taxes in the next period and therefore, by putting forth that it shall distort the efficiency of the market, he has stated that there is no method of public finance" (Çalcal1, Ö. 2013: 105). Unless obligatory, they prefer not to make use of debt and it is put forth that the debt is a burden for the future generations (Arsan, Ü. 1973: 158). Keynesians assert that the state should not be afraid of debt and when necessary, debt should also be taken just like other resources with comfort.

J. According to the Classical Theory, when the economy is let to be alone, namely when there is no intervention of the state in the economy, the economy comes to the balance at the level of full employment by itself. For this reason, unemployment does not occur in the economy (Bocutoğlu, E. 2009: 162). Classical price theory states that the price limit changes depending on the effort, supply and demand and does not accept nonvoluntary unemployment (Nadaroğlu, H. 1985: 97).

However; according to the Keynesian Theory, when the economy is let to be alone, namely when the state does not intervene in it, the economy cannot come to the balance at the level of full employment by itself, it comes to the balance at the level of deficient employment by itself and unemployment occurs. For this reason, the state should intervene in the economy by means of its fiscal and monetary policies (Bocutoğlu, E. 2009: 163; Aktan, C.. C. \& others. 2010: 2).

$\mathrm{K}$. There is a directly related relation between the labor supply and real price and a reverse related relation between the labor demand and reel price. When the real price increases, the labor supply decreases and when the real price decreases, then the labor supply also decreases. When the real price decreases, the labor demand increases, when it increases, the labor demand decreases. According to the Classical Theory, the 
prices and fees are fully flexible (Yildırım, K. vd. 2010: 119; Chan, F. 2014). In full employment, the prices and fees change depending on the changes in the demand (Nash, J. 2014). According to this, when the total demand increases, the general level of the prices decreases. Because the economy is permanently in the balance at the level of full employment, when the total demand increases, the amount of production does not increase, only the general level of the prices increases; when the total demand decreases, the production amount does not decrease, only the general level of the prices decreases.

In the Keynesian Theory, while the economy is in balance at the level of deficient employment, there are suspicions in the issue of the fact that the prices and especially the fees are flexible (Yildırım, K. \& others. 2010: 146), the prices are strict, namely according to the Keynesian theory, the prices and fees are not flexible (Chan, F. 201) . Namely, while the economy is in balance at the level of deficient employment, when the total demand increases, the general level of the prices does no increase and when the total demand decreases, the general level of the prices does not decrease. Keynesians believe that the prices and especially the fees give a too slow reaction to the changes in the supply and demand ((Jahan S. \& others. 2014: 53; Blinder, A.S. 2014). Because economy is in balance at the level of deficient employment as a rule, when the total demand increases, the general level of the pries does not increase, but the amount of production increases. In return for this, when the total demand decreases, the general level of the prices does not decrease, but the amount of production decreases (Bocutoğlu, E. 2009: 163).

L. According to Adam Smith, richness does not occur by means of the gold or silver, actually it occurs by purchasing effort (Smith, A. 2001: 37), the effort is the real price of the products, money is only the nominal price of the products (Smith, A. 2001: 39). According to the Classical economists, money is a means of exchange used in the shopping and the changes occurring in the money supply apply pressure directly and only at the level of prices (Öztürk, N. 2012: 28). In the Classical Theory, the monetary changes cannot affect the real variables. This is called Classical Dichotomy. For example, the money supply is a monetary variable. The employment and production level are also real variables. As per the principle of Classical Dichotomy, the increases in the money supply only increase the general level of the prices, but it cannot affect the employment and production level. For this reason, according to the Classical Theory, money is impartial, namely it does not have any impact on the employment and production (Bocutoğlu, E. 2009: 164);

In return for this, according to the Keynesian theory, while the economy is in balance at the level of deficient employment, namely when there are deficient capacity usage and unemployment in the economy, the monetary variables could affect the real variables. For example; while the economy is in balance at the level of deficient employment, when the money supply is increased; the total demand, employment and production amount increases, but the general level of prices does not increase. For this reason, according to Keynes, while the economy is in balance at the level of deficient employment, the principle of Classical Dichotomy is not valid, the money is partial, and namely it is efficient on the employment and production level (Bocutoğlu, E. 2009: 164).

\section{Conclusions}

The fact that the private sector is based on price, benefit and profit, it gives importance to giving individualized goods and service, it does not take the social and communal benefit into consideration, all the solutions are possible with the mechanism of invisible hand in the market and at this point, their assertions of being against the intervention of state are insufficient in the realization of the purposes such as the termination of the states of instability and stability-development, fair income distribution etc. At the point of solution, the active intervention of the state by its fiscal policy has become obligatory.

The income and expenses equality is researched in the equality principle being the basic philosophy of the classical system. The Classicals giving so much importance to the equality have applied wrong policies in various instability states as a result of this point of view. That is to say;

$i$. Because the incomes decrease in the recession periods, they have applied the policy of decreasing the expenses (equality) and caused the existent recession to increase more;

ii. Because the incomes increase in the boom and inflationist period, they have applied the policy of increasing the expenses (equality) and the expense-increasing caused the existent recession to increase more;

Against these policies, the supporters of the periodic budget view have given place to more positive and correct policies and they have applied the policies 


\section{Engin Öner /International Journal of Finance \& Banking Studies \\ Vol 4, No 2, 2015 ISSN: 2147-4486}

giving budget excess in the inflationist environments and applied policies giving budget deficit in the deflationist periods.

The philosophy of the budget balance (fiscal balance) of the Classicals is seen as the ideal balance and it is put forth that the budgets to have deficiency or excess shall cause to the inflationist or deflationist pressures. However, the classicals have neglected the fact that the public expenditures $(\mathrm{G})$ shall apply inflationist pressure to the taxes (T) according to the multiplier coefficients (public expenditure multiplier $=[1 / 1-\mathrm{c}] ;$ tax multiplier $=$ [-c/1-c]) although the income and expenses are numerically equal. The multiplier of transfer expenditure (c/1-c) has the same impact with the tax multiplier; but the real expenditure multiplier increases the inflationist tendency as long as there is no increase in the production with its expander impact.

In addition, the equal budget policy specified by the Classicals as the aim is used as a means today; the economical balance rather than the fiscal balance creates more positive results.

Together with the fact that going into debt is preferred to be deemed as an ordinary income instead of extraordinary income; in most countries, going to excessive debt has faced the countries with serious debt loads. As well as the growth models with demand-only sources, the importance of the models based on supply should not be neglected.

Keynesian theory which has occurred as based from the weak points of the classical school has become successful in the first periods it has been applied, but it could not be sufficient in explaining the new problems occurring later on (stagflation which means "the partial recession with the inflation with high rate and with employment with high rate" and the slamflation which expresses "the situation in which the employment with high rate and the inflation with high rate are experienced together"). The supply-supportive economists, monetarists, constitutional economists etc. revealing later on and the Keynesian theory and especially the intervention of the state have been strictly criticized. This reveals that no schools could provide a perfect solution within time all alone.

Nevertheless; on condition that it shall be limited in terms of the assumptions and principles we have examined in this study, it could be concluded that the Keynesian theory seems more consistent than the classical thought in terms of the social and communal benefit, applications related to the collectivist services, the functions they load to the state, the solutions they reveal in the struggle with the inflation and deflation etc.

\section{References}

Akdogan, A., S. Kurbaş \& S. Eyüpgiller, (1986). Açıklamalı Maliye ve Vergi Sözlüğü, Birlik Yayıncılık Ltd. Şti. 1. Baskı, Ankara.

Aksoy, Ş., (1998). Kamu Maliyesi, (Kamu Harcamalar1Kamu Gelirleri-Devlet Borçlar-Bütçe-Maliye Politikası). Gözden Geçirilmiş ve İlaveli 3. Bask1, Filiz Kitapevi. İstanbul.

Aktan, C. C., (1992). Kamu Ekonomisinden Piyasa Ekonomisine: Özelleştirme. Ankara.

Aktan, C.C., D. Dileyici \& A. Özen, (2010). "Kamu Ekonomisinin Yönetiminde İki Farklı Ekonomi Politikası Yaklaşımı: İradi ve Takdiri Kararlara Karşı Kurallar". T.C. Maliye Bakanlığı, Strateji Geliştirme Başkanlığı Yayın No: 2010/408, Ankara.

Arsan, Ü., (1973). "Kamu Borçlarının Yükü Sorunu", Ankara Üniversitesi SBF Dergisi. Cilt: 28 Sayl: 3. pp. 157-172. Ankara.

Ay, H., (2014). Kamu Maliyesi. Gözden Geçirilmiş 2. Basım, Nobel Akademik Yayıncılık Eğitim Danışmanlık Tic. Ltd. Şti. Ekim.

Aydın, Y., (2013). "Say Yasası: Keynes'in Yorumu ve Son Dönem tartışmaları", İktisat Fakültesi Mecmuası Cilt: 63, 2013/1 pp. 81-130.

Bilici, N. \& A. Bilici., (2011). Kamu Maliyesi. Seçkin Yayıncılık san. Ve Tic. A.Ş., Birinci Baskı, Ankara - Ekim.

Blinder, A. S., (2014). "Keynesian Economics". The Concise Encyclopedia of economics. http://www.econlib.org/library/Enc/KeynesianEc onomics.htm (date accessed: 01.09.2014)

Bocutoğlu, E., (2009). Makro İktisat. Teoriler ve Politikalar. Yenilenmiş ve Genişletilmiş Beşinci Bask1. Murathan Yayınevi, Trabzon.

Bocutoğlu, E. \& A. Ekinci, (2009). "Genel Teori, Küresel Krizler ve Yeniden Maliye Politikası", Maliye Dergisi. Sayı 156. Ocak-Haziran 2009. pp. ersanbocutoglu.net/Custom/OdesisMc/malpol.pd $\mathrm{f}$ (date accessed: 21.11.2014)

Chan, F., (2014). "Classical and Keynesian Economics". http://staffwww.fullcoll.edu/fchan/macro/3classi 
cal_and_keynesian_economics.html_ (date accessed: 01.11.2014)

Çalcalı, Ö., (2013). "Kamu Maliyesi Perspektifinden Adam Smith", International Journal of Economic and Administrative Studies (Uluslararast Iktisadi ve İdari Incelemeler Dergisi) Year: 6, Number 11, Summer 2013 pp. 89-108

http://www.arastirmax.com/system/files/dergiler/ 194000/makaleler/6/11/arastrmx_194000_6_pp_ 89-108.pdf (date accessed: 21.11.2014)

Devrim, F., (1996). Kamu Maliyesine Giriş. Anadolu Matbaacılık Ltd. Şti. İzmir.

Dikmen, O., (1995). Liberal, Bitaraf ve Müdahaleci Vergi Politikaları, İ.Ü. İktisat Fakültesi Maliye Enstitüsü, Yayın No: 665-85-1. İstanbul.

Edizdoğan, N., (2007). Kamu Maliyesi. Güncelleştirilmiş 9. Baskı, Ekin Kitabevi, Bursa.

Eker, A., A. Altay \& M. Sakal, (1994). Maliye Politikası (Teori, İlkeler ve Yöntemler), Takav Matbaacılık, Yayıncılık San. Ve Tic. AŞ. Ankara.

Erginay, A., (1990). Kamu Maliyesi. Gözden Geçirilmiş ve İşlenmiş 13. Baskı. Savaş Yayınları. Ankara.

Forstater, M., (1999). "Functional Finance and Full Employment: Lessons from Lerner for Today?". Working Paper No. 272. The Jerome Levy Economics Institute July 1999 http://cas.umkc.edu/econ/economics/faculty/Fors tater/pubsindex.htm (date accessed: 20.11.2014)

Forstater, M., (2008). "Economics of Control". International Encyclopedia of the Social Sciences: Ed.William A.Darity Jr. Vol 2. 2nd.Ed. Detroit:Macmillan Reference USA, 2008.pp.531533.http://cas.umkc.edu/econ/econo mics/faculty/Forstater/papers/Forstater2008/Econ omicsOfControl.pdf (date accessed: 21.11.2014)

Giray, F., (2010). Maliye Tarihi. Ezgi Yayınları.Üçüncü Baskı. Eylül, Bursa.

Güngör, K., (2014). “İktisadın Tarihine Kısa Bir Bakış ve Merkantilizmden Günümüze İktisadi Düşünceler"

http://www2.aku.edu.tr/ kgungor/kamil_gungor. pdf (date accessed: 16.11.2014)

Jahan S., A. S. Mahmud \& C. Papageorgiou, (2014). "What Is Keynesian Economics?". Finance \&
Development, September 2014, Vol. 51, No. 3, pp. $\quad 53 \quad-\quad 54$. http://www.imf.org/external/pubs/ft/fandd/2014/ 09/basics.htm (date accessed: 14.11.2014)

Kamalak, M., (1985). Kamu Borçlanması. Atatürk Üniversitesi. "İİBF Araştırma Merkezi Ders Notlar1: 115, Erzurum.

Keynes, J. M., (2008). Genel Teori İstihdam, Faiz ve Paranın Genel Teorisi. (çev. Uğur Selçuk AKALIN), Birinci Basım, Kalkedon, Ocak.

Keynes, J. M., (1936). The General Theory of Employment Interest and Money. Rendered into HTML on Wednesday April 16 09:46:33 CST 2003, by Steve Thomas for The UniversityofAdelaideLibraryElectronicTextsColl ection."cas.umkc.edu/economics/people/facultyp ages/kregel/.../generaltheory.pdf” (date accessed: 01.10.2014)

Lerner, A. P., (1943). "Functional Finance and the Federal Debt." Social Research, Vol. 10, No. 1, February, 1943, pp. 38-52. http://delong.typepad.com/sdj/2013/04/abbalerner-1943-functional-finance.html. (date accessed: 21.11.2014)

Lerner, A. P., (1947). "Money as a Creature of the State." American Economic Review 37. 1947 http://www.jstor.org/stable/1821139 (date accessed: 20.11.2014)

Nadaroğlu, H., (1985). Kamu Maliyesi Teorisi. Genişletilmiş ve Gözden Geçirilmiş 6. Bask1. Beta Basım Yayım Dağıtım A.Ş., İstanbul.

Nash, J., (2014). "The Keynesian Model and the Classical Model of the Economy". http://education-portal.com/academy/lesson/thekeynesian-model-and-the-classical-model-of-theeconomy.html\#lesson. (date accessed: 13.11.2014)

Orhan, O. Z., 1989. Keynezyen ve Moneterist İstikrar Politikaları, Bilim Teknik Yayınevi. İstanbul.

Orhaner, E., (1992). Kamu Maliyesi. Gazi Üniversitesi. Emek Kitabevi, Ekim / Ankara.

Özkara, M., (2014). "Devlet Anlayışında Ortaya Çıkan Değişikliklerin Sonucu Olarak Vergilemeye Yüklenen Fonksiyonlar" http://www.alomaliye.com/mehmet_ozkara_devl et_anlayisinda.htm (date accessed: 01.11.2014)

Öztürk, N., (2012). Maliye Politikası. Ekin Yayınevi, Mart. 
Öztürk, N., (2013). Kamu Maliyesi. Ekin Yayınevi, Ağustos.

Pehlivan, O., (2013). Kamu maliyesi. Celepler Matbaacılık, Yayın No: KM 14, Trabzon Ağustos.

Pehlivan, O., (2014). Devlet Bütçesi. Celepler Matbaacılık, Yayın No: DB 1, Trabzon - Eylül.

Pettinger, T., (2008). "Definition of Full Employment". http://www.economicshelp.org/blog/453/unempl oyment/definition-of-full-employment/ (date accessed: 15.11.2014)

Smith, A., (2001). Ulusların Zenginliği. (çev. Ayşe Yunus ve Mehmet bakırcı), Alan Yayıncilık, No. 37, Üçüncü Baskı, Kasım.

Smith, A., (2002). Ulusların Zenginliği Cilt 2. (çev. M. Tanju Akad). Alan Yayıncılık, No. 195, Birinci Bask1, Kasım.

Savaş, V. F., (1997). İktisadın Tarihi, Liberal Düşünce Topluluğu. Avcıol Matbaacıllk, İstanbul.

Turhan, S., (1975). Vergileme ve İktisadi Büyüme. İstanbul Üniversitesi Maliye Enstitüsü Konferansları, Seri:23. İstanbul.

Türk, İ., (1988). Maliye Politikası, 7. Bası, S yayınları, No. 15, Ankara- Ekim.

Türk, İ., (1992). Kamu Maliyesi. Turhan Kitabevi, 1. Baskı. Ankara.

Vitez, O., (2014). "Differences Between Classical \& Keynesian Economics". http://smallbusiness.chron.com/differencesbetween-classical-keynesianeconomics3897.html. (date accessed:13.11.2014)

Yıldırım, K., D. Karaman and M. Taşdemir., (2010). Makroekonomi. 9. Baskı. Seçkin Yayıncılık San. ve Tic. A.Ş. Ankara. 